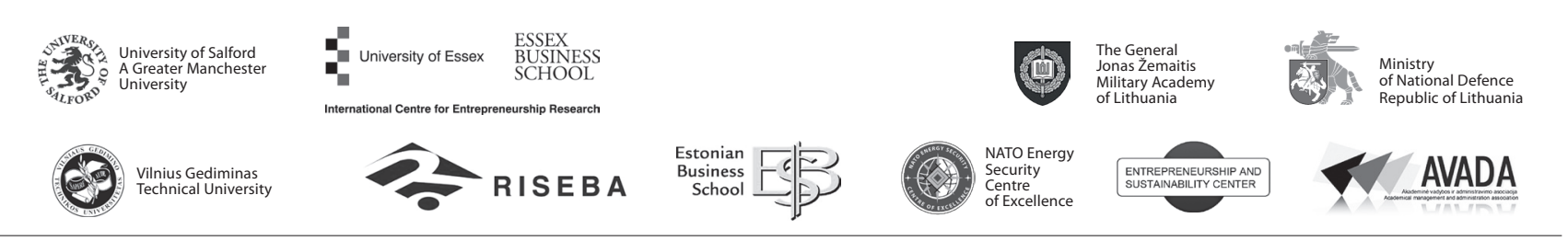

JOURNAL OF SECURITY AND SUSTAINABILITY ISSUES

ISSN 2029-7017 print/ISSN 2029-7025 online

2017 December Volume 7 Number 2

https://doi.org/10.9770/jssi.2017.7.2(2)

\title{
THE MANAGEMENT OF TERRORISM ROOTS AS A PREREQUISITE FOR SUCCESSFUL FIGHT AGAINST TERRORISM
}

\author{
Darijus Beinoravičius ${ }^{1}$, Milda Vainiutè2 \\ 1,2Mykolas Romeris University, Faculty of Law \\ Address: Ateities str. 20, LT-08303 Vilnius, Lithuania \\ E-mails:dabein@mruni.eu',milda.v@mruni.eu²
}

Received 15 March 2017; accepted 20 November 2017

\begin{abstract}
In this article, the problem of terrorism is discussed in view of the peculiarities of legal nature. The phenomenon of terrorism is being analyzed by scientists in the political, economic, socio-psychological point of view and more attention is paid to the legal theoretical characteristics of this phenomenon. A more detailed analysis of terrorism in the article shows that use of concept of terrorism, regardless of reasons for this, makes the fight against terrorism an ideological tool, posed together as a growing threat to human rights. Furthermore, this article analyzes the reasons of terrorism and provides tendencies for further development of global terrorism. When there is no clear definition of terrorism and its causal relations are acceptable to all, questions concerning the scope of the fight against terrorism arise. In this case, we cannot be sure that modern democratic countries use the correct definition of terrorism in all cases and do not violate the human rights when fighting against terrorists. Even more doubts about the actions of democratic countries participating actively in fight against terrorism arise. The uncertainty of terrorism concept is being used to conceal violations of the human rights.
\end{abstract}

Keywords: security, terrorism, terror, process of democracy, digarchy

Reference to this paper should be made as follows: Beinoravičius, D.; Vainiute, M. 2017. The management of terrorism roots as a pre-requisite for successful fight against terrorism, Journal of Security and Sustainability Issues 7(2):193-202.

https://doi.org/10.9770/jssi.2017.7.2(2)

JEL Classifications: Q3

\section{Introduction}

Security and safety nowadays has become precondition of sustainable development (Teivāns-Treinovskis et al. 2016; Ivančík, Nečas 2017; Tumalavičius et al. 2017). The quote „one man's terrorist is another's freedom fighter "has become not only a cliché, but also one of the most serious obstacles in the fight against terrorism phenomenon, which directly affects security and safety of societies. Today terrorism is expanding beyond the borders of one country thus increasing the risk of fear and conflict in the realtionship of countries. Nations of Russia, Iran and China, whose strategic public policy priorities is to keep the economic development of those countries, their influence in particualr regions and withstand against the interests of the United States of America (hereinafter - the USA), fight more strongly against the USA which has dominated for a long time and still is dominates in global politics. Other countries choose relative positions in these relations: in Europe France opposes the USA policy, Germany is annoyed because of it and the United Kingdom demonstrates its allegiance. In Eurasia, the Japanese silence tells more about its frustration rather than approval of the USA's influence in the world. Some nations of world do not understand why the USA drives to focus only on the Middle Eastern Asian countries which are rich in natural resources: Kuwait, Iraq and Saudi Arabia. It allows to suggest that the 
USA is forced to transfer its economical ambitions to policy priorities, as the needs of consumer society in that giant country are constantly growing.

Evergrowing aggressive interests of countries of consumer societies' show rising roots of possible conflicts (and terrorism, because this phenomenon can only be properly understood in the context of the legal sociological and political science), i.e. faults, which are the starting point for finding appropriate means to solve the arising problems. In other words, the methodological position of the article is that it is necessary to search for the solution of the problem by analyzing the faults of the phenomenon. From many authors who have been analyzing terrorism in recent years, we can mention the famous lawyers - political scientists Emmanuel Todd, Paul Kenedy, Samuel Huntington, Zbigniew Brzezinski, Henry Kissinger, Robert Gilpin, who unanimously admit that the "weakest point of global conflicts" is the aggressive policy of USA to have an impact in the world being (Todd, 2004; Kennedy, 1989; Huntington, 1998; Brzezinski, 1997; Kissinger 2001; Gilpin, 2001). This influence is facing growing resistance of other countries developing democratic societies, therefore, according to the mentioned authors, due to rising confrontation the USA must relatively reduce its ambitions to spread its power over the developing world which is rapidly developing and becoming abundlanty inhabited and more democratic.

In the article taking terrorism as problems of terrorism conception are discussed legal aspect of phenomenon into consideration. In current society the conception of terrorism is becoming ever more and relevant as we constantly hear about it on the radio, television and read in newspapers. Popularly speaking about terrorism, usually all facts are based on emotional arguments. The need of more comprehensive analysis of this phenomenon induces to analyze terrorism deeply, as the use of the concept of terrorism, not concerned with the reasons of it, supposes the fight against terrorism itself as an ideological tool that poses a threat for human rights. This article analyzes the reasons of terrorism and further tendencies of its development. When there is no clear and mutually acceptable definition of terrorism, questions arise about the sensibility and well-foundedness of fight against terrorism. In this situation, nobody can be sure, if contemporary democratic states in all cases uses right conception of terrorism and fight against terrorism not breaking human rights. Terrorism conception cannot be abstracted from revealing of its descent.

Democracy as progress, is in progress where it is weak and regresses where it was strong. States with growing democratic processes express more interests, whereas the oligarchies do not want to let them have influence over their zones of economical interest. Then conflicts are raised as there is no interest for oligarch and economical and military stronger states to reach compromises. The states that are not able to defend their interests are left only with radical methods of fight, that at first distinguish with their conditional cheapness and great psychological influence. This is the reason why terrorism that is one of the means to fight and defend ones rights and interests, is becoming so popular in the world. In this article universal concept of terrorism, that is reasonable for the Old world states, is criticized.

\section{The concept of terrorism and its meaning}

Terrorist attacks have long been a global threat. Almost every day there are terrorist attacks executed somewhere. Due to everspreading globalization, this threat is increasing, because using modern means of communication terrorists can spread their ideology, recruit new members, plan and coordinate terrorist attacks not meeting face to face. Therefore nowadays, everyone is under threat of terrorist attacks, despite of national borders, nationality or religion. Terrorism is one of the most dangerous and unpredictable phenomenon of our times, which is gaining a great variety of forms and a more threatening scope. Terrorist attacks usually bring massive loss of people lives and are related with the destruction of both material and spiritual values, which sometimes can not be restored. Furthermore, terrorist attacks also show hostility between countries, provoke distrust, hate between social or ethnic groups or even wars that sometimes can not be resolved over the life of one generation.

After terrorist attacks of September 11, 2001, during which nearly 3,000 people were killed, the United States declared war on terrorism and have taken military action against the terrorist group Al-Qaeda in Afghanistan. 
On September 12, 2001, NATO for the first time in its history has decided that if it had been determined that these attacks have been carried out from abroad, the Article 5 of the North Atlantic Treaty would have been applied. The fight against terrorism, which was initially held in the level of cooperation between countries and law enforcement actions, has penetrated into the area regulated by international humanitarian law. The recent magnitude of terrorism forces us to look at it not only as an ordinary crime, but also as a socio-political phenomenon of critical importance, which can significantly change the modern world order and can deform the democracy due to the threat posed to the human rights. In conditions of globalization, new social groups, nations, countries and even civilizations are awakening to implement and defend their rights. Sometimes it includes terror as a mean of making influence on the political decisions and raising horror for the civilians. This forces everyone to rethink the interpersonal communication (Vaišvila, 2005) basics between nations and different social groups in conditions of expanding globalization: what these relationships should be based on so that the hazards of integrating world for people and democracy would not increase.

The term of terrorism was first introduced in 1793, describing terror authority, carried out by M. Robespierre, when he together with other leaders of the state sought to kill the enemies of the revolution and founded the dictatorship to stabilize the state. Later on, terrorism was used by individuals and non-derivatives rather than the states. This „,non-state“ terrorism has spread in the second half of twentieth century. It was used as an additional tactics by nations, fighting for the independence. Most usually terrorist attacks were part of a greater action program. Terrorism has gained the international dimension mostly in the sixties of twentieth century, when aircraft hijacking became popular. Various political groups sought to draw attention to their political aspirations using the terrorist attacks. In this time, terrorist groups have begun cooperating with each other. Since the nineties of twentieth century religiously motivated terrorism was mostly widespread.

The concept of terrorism is important both in political and social sciences. On the other hand, it is difficult to find any other word, which in today's political discourse would be more controversial than terrorism. None of the many definitions of terrorism has become universally accepted. Trying to define terrorism universally primarily is concerned with political and ideological problems. Terrorism is a relative term and it depends on how it is defined by the concerned party. In other words, what is terrorism and what is not terrorism, depends largely on whether the rating stems from the victim or from the violator's side. Still, in most cases terrorism is defined as a planned violent action of sub-state level or threat directed against civilians, aimed at political objectives - to cause panic in society, to express political protest against the state, to undermine or overthrow the government, to change the political system. This definition includes three key elements, which are characteristics of all modern definitions of terrorism: violence, civilians and politics. Modern term of terrorism should be interpreted more broadly and include not only a variety of terrorism-related offenses used in international documents, but also the threats and risks to internal national security. In this sense, terrorism can be defined as synthesis of threats or danger and of military actions with the purpose to address specific political or national questions, using violence or terrorist acts against the state, its official institutions and citizens (Dranseikaite, 2002).

A specialist of terrorism, R. A. Hudson (Hudson, 1999, p. 8), defines terrorism as "violent activity that is unexpected to victims, opposed to criminal law, which aims to make the psychological impact on the addressee, to draw attention of society to certain problems, requirements and to achieve the objectives of the group". The term "terror" is coming from the Latin word "terror" which implies horror, fear, fright (Kuzavinis, 1996, p. 858). The literature contains a number of terrorism definitions: one describes a methodology for the operation of terrorist organisations, others - stress the terrorism motivation and singularity, single terrorist activity plans and so on. In the book "Political Terrorism" Jongman and Schmid Jongman provide 109 definitions describing terrorism (Jongman, Schmid, 1988, P. 33). The horror, fear and fright are the most usually recurring keywords in these definitions. Fear, as a mean of fight against terrorism, is often referred to the mean of destabilisation or deposing of existing political institutions.

Problem of description is a key element of the fight against terrorism, trying to coordinate international cooperation based on the current acceptable rules of common war, separating terrorism from normal criminal facts, from the open war between groups in conflicts, from actions, that are clearly understood as results of mental 
retardation. To sum up, it can be said that when there is no clear definition of terrorism that is acceptable to all and its causal relationships are not understood in the same way, questions of the scope and validity of the fight against terrorism arise. We cannot be sure that modern democratic states use the correct definition of terrorism in all cases. In this case, even more doubt about the actions of democratic countries participating actively in fight against terrorism arise. Perhaps the uncertainty of terrorism concept is used to conceal human rights violations?

Terrorism as a phenomenon in particular stands out for the fact that terrorism is not only trying to cause panic, but to undermine trust in government or the dominant policy of the country too. Thus, terrorism operates through the psychological impact frightening, and terrorising the society. The social impact of terrorism today is particularly increased by two important factors: (1) technical inventions of modern weapons ${ }^{1}$ and 2) developing ability of the media to inform the world about certain requirements disseminating fear. Most of terrorist groups are usually composed of few members, have a limited amount of ammunition and relatively little organizational resources. For this reason, they depend on elements of "an unexpected attack and retreat" that are dramatic, often effective, bloody, destructive and violent acts, so when summarizing we can argue that terrorism is the deliberate use of violance against civilians or civilian targets in order to achieve political objectives. This concept includes three important elements:

1. Operational method - the usage of violence, threats of violence. According to this characteristic, activity, that doesn't include violence or threat of violence, is not considered terrorism (including non-violent protests strikes, peaceful demonstrations, etc.).

2. Operational objective is always political - to achieve the implementation of political requirements: changed form of governance, social or economic policy, the governments and so on. Activities, having non-political purposes, shall not be considered to be terrorist. The violent activities against the civilians, having no political aspirations, illegal criminal or just actions of mentally affected human are not related to terrorism. Some researchers tend to add the ideological and religious aspirations to the list of the political objectives. The term must be brief and, as far as possible, complete. The idea of "political objective" is quite broad, including other objectives too. Motives should not be linked to the concept of political terrorism. Most analysts tend to discuss about the clear reasons as logical or necessary aspects of terrorism, but they are not clear and very often only complicate the research. A theoretical version is not rejected that after the acceptance of the political objectives, while motives stay the same, terrorist attacks would end in any case, for example, Chechen women joined the fight encouraged also by those reasons that their brothers, sons and husbands were killed. After Russia accepted a Chechen militant claims, women, like other fighters, would leave the fight though their reasoning would stay consistent and they still would not be able to forget the suffered grievances.

3. The subject of terrorism - civilians. Because of this reason terrorism stands out from other kinds of political violence (e.g., civil wars, civilian riots). This method of destruction is based on the vulnerability of the civilian population: attacks on the unarmed victims raise the concern of the majority of people, draws attention of the media.

\section{The identity of terrorism and other conflicts' reasons}

The phenomenon of terrorism is known since the establishment of the first "terrorist organisations" that were two Jewish extremists groups "Sicari" and "Zealots". These were established in ancient Rome in AD 46, when members of the two groups in fights against the Greeks, Romans and schismatic Jews were not avoiding to use violence. Often the victims in the Roman Empire were killed in public in order to pass a message to the Roman authorities. Although the origins of terrorism aims the 1st century (Diržytè, Patapas, 2003, P. 31), the theories of terrorism launched only in the twentieth century.

1 For example, the production of weapons in the USA is in the first place in terms of profitability. 
Terrorism has evolved over thousands of years, rapidly changing its ideology and methods of operation. This is a very varied and evolving phenomenon, which has experienced very rapid progress in recent decades. Terrorist ideologies can be created distorting any system of beliefs: patriotism, religious feelings and political views. Ideologies of terrorism are very different, but they are all characterized by the same strategy: to intimidate the society using violence against innocent people and to achieve their goals. This strategy is universal and it is a common trait of all terrorists starting from left to right. Despite the absurdity and cruelty of terrorism strategy, the values for which terrorists are fighting make sense and can be logically explained through historical cognitive approach, analysing the geopolitical situation, its development as well as understanding elementary human feelings. This does not justify terrorism but it suggests, that causes of terrorism can be identified and understood, and hence the most important conclusion is that removal of terrorism causes can prevent the phenomenon (Paukšte, 2005, p. 89). That terrorism and other forms of political violence are a product of poverty and poor distribution has become a core assumption among national and international policymakers since the events of Septembert 11 (Piazza, 2006, p. 159).

Terrorism is more than ever relevant today, as on 20 September 2001, President of the United States George W. Bush said: "either you are with us or you are with the terrorists". There were no neutrals in regard of the USA. "The goodness is struggling with evil". The whole world has become a place for the fight against terrorism. But whether groups calling themselves terrorist, for example, the Hezbollah (supported by Iran), Abu Nidal Organization (backed by Syria, Libya and Iraq), the Japanese Red Army (often under contract acts with Libya), the Baader-Meinhof Group (Germany), "The Weathermen" (America, 1970), the "Red Brigades" (Italy) and many other organizations endeavor and conflicts are not similar to other national and global conflicts, of which there is plenty around the world?

During last 15 years we were observing the genocide in Rwanda, religious strife in Nigeria, Somali clan battles, civil war in Sierra Leone, the apartheid regime in South Africa, killing of farmers in Zimbabwe, the mass terror in Algeria. We have heard about the Islamic revolution in Iran, following the Chechen conflict, anarchy in Georgia, we kept tracking Armenia's and Azerbaijan's war on Karabakh, resistance of Kurdish separatists in Turkey, the civil war in Tajikistan, the Kashmir conflict in India, the tamils' rebellion in Sri Lanka, Muslim war in the South of the Philippines, the Taliban regime in Afghanistan and many others. Left-wing militant attacks are taking place in Colombia, South America. Decomposition conflict of Yugoslav Croatian and Bosnian Muslim, Serbs, and Kosov is taking place in Europe. In other words, we have realized that violence can occur in our country too. These conflicts, in accordance with the current U.S. position, could be "quieten" by force, by hitching labels of the terrorist attacks. The reasons of terrorism and other conflicts are similar, differing only in the counter measures and techniques.

Conflict is undoubtedly a result of the controversy. Disagreement appears then, when there is a dispute, the parties of the dispute do not look for compromise solutions. Only equal countries are interested to search for a compromise. If one party is stronger, it is unnecessary to compromise for it, because it can win using its strength and guarantee the implementation of its interests using power. Similar situation has arisen in the world lately, when powerful countries are not looking for compromises and expect to maintain their possitions by force. In this case, the balance between the rights and obligations of cross-border relations is re-adjusted. The powerful parties enforce their own rights to the weaker and in such way unreasonably upstage the interests of citizens. Terrorism is a result of balance infringement between the rights and obligations of cross-border relations. Terrorism, as a low-cost way of fighting, becomes the only way for the weaker party to express and declare its requirements for a stronger party of the conflict and for the whole world. Paradoxically, terrorism today is directed against countries considering themselves as democratic countries.

It shall not be forgoten that democracy is also a process, and it may change, because the history doesn't stop. When democracy provides the greater part of society more equal rights, law in society is ontologized and society differentiation emerge from the same start positions, as not all in the society reach equally under the same conditions. The democracy inevitably turns into an oligarchy in such process. Aristotle was already speaking about this. Therefore, in agreement with E. Todd, we can argue that the old democracies - the United Kingdom, 
France and the USA - are transformed into oligarch countries, because democracy progresses there, where it was weak, and regresses there, where it has been strong (Todd, 2004, P. 33). In Asia democratic processes are getting only stronger, while in the West, in particular in the United States, they might be going weaker. The ideological and economic role of the USA in the world after the Second World War was favourable to grow for USA's oligarch system together with the interests of the consumer society. After emergence and reinforcement of democracy in other countries of the world, the USA's aid has become an irrelevance. The USA's aid gives it the rights to have vested interests in those regions. Not in vain the USA's aid is directed to the rich and promising, yet untapped economic zones. The USA have an interest to never fully unsettle conflicts that it could whenever justify its military actions in respect of the "care" in these areas. Therefore, it is understandable why the USA fail to finally regularise the conflict between Israel and the Palestinians and why it did not effectively resist against soviet occupation in Lithuania.

Democracy always encourage the openness of society and it highly develops when two important factors act: 1) literacy growth and 2) birth restrictions (Todd, 2004, p. 44). The education factor promotes migration processes not only to America, but also to the Europe. The decline in the birth rate gives more freedom for families, in particular women, so a small model of democracy first emerges in the smallest cell of society - the family. With fewer children, the family becomes more mobile and socially active. There are two universal factors in the increase of literacy and the decline of the birth rate that determine the spread of democracy, because in the new democracies literacy and birth rate are growing significantly and are becoming similar to the statistical indicators of Western democratic countries.

The new democracies begin to claim their rights and the old are reluctant to give way to their positions. We can explain it not only by ideological aspects, but also by the interests of society in the sociological insights. Liberating society of the new world democratic states declares more interest while clan of old democracies 'oligarchs do not want to to give up their influence -"trusteeship", i.e. the economic and other areas of interest. And then the conflict arise, that the oligarch, still economically and well performing countries do not have reasons to find a compromise. And new, still not powerful countries, incapable to defend their interests in open processes, are left only radical methods of fight that at first distinguishes their conditional cheapness and great psychological influence. So this is a reason why terrorizm is becoming so popular in the world and which is often the only way to fight for rights and interests.

Events of 11 September 2001 in New York City are definitely misinterpreted in the guise of "conflict of civilizations". The Western world, promoting tolerance values, explaining conflict in this way, though this interpretation is very common, presents superficial and primitive reasons of terrorism. In recent years, Pakistan and Saudi Arabia by the expansion of literacy and the decline in the birth rate jumped an extreme leap towards modern and democratic countries. The concept of universal terrorism is positive to those countries, which organizes the global "crusades," and set up its own military bases in no matter where - in the Philippines or in Yemen, Uzbekistan, Georgia or Chechnya or Afghanistan. The concept of global terrorism has neither historic nor social justification, because it does not correspond to the actual situation. The universal concept of terrorism is necessary only to those old world countries, which regard themeselves developed, which need an excuse to constantly monitor the situation and intervene in constant wars of the third world, to suppress them and never finish this process.

Forms of political coercion usually prevail at the times of social crises. What we are facing nowadays is a new turning point in social development, namely, a transition to the age of information. This transition to the age of information coincides with the expansion of globalization. Not only is globalization becoming a dimension of human existence, but also a context of international terrorism. International terrorism poses a powerful challenge to the vitality of the democratic political models of Western societies in the epoch of globalization and information. Therefore antiterrorist ideology should be based on the reciprocity of state security and individual security. A relationship of this kind should be considered a regular condition for the coexistence of social subjects (Šlapkauskas, 2005. p. 34.), when the ideology of fight against terrorism emphasizes the fundamental necessity of the legal protection of human life and dignity. 
Terrorism may be the litmus paper, which is clearly proving the fact that the degree of implementation of law and justice is already depleted of its creative possibilities to continue to do so under conditions of globalization, when new social groups, nations and even civilizations come to the social arena, reaching an equitable part in the development of modern social cohabitation arrangements both inside specific country and internationally. Therefore, the modern world, which in conditions of globalization want to ignore every issue of concern in finding and expanding rights and the need for justice, absolute interests of individual nations and social groups, change equal cooperation into dictate, it becomes dangerous to itself (Vaišvila, 2005, p. 11). Terrorism can be seen as first clearly expressed prophet of this awakening threat and a developer of the society's need to reform.

\section{Some tendencies of terrorism and the fight against terrorism}

Since the nineties of twentieth century terrorists started to plan particularly large-scale terrorist attacks, which can be said to encroach not only to individuals but also to the national security and territorial integrity. Terrorist attacks violate various rights of individuals. Rights to life, liberty and security of person are being violated the most. Especially in those countries, where terrorists hold series of terrorist attacks, the insecurity environment formed in a society affects all areas of public life, including the social environment, economy, education and other spheres. Countries in response to the threat of terrorism and to protect the rights of persons within their jurisdiction, have the right and duty to take effective action against terrorism, to seek to prevent future terrorist attacks and to prosecute those who are responsible for such actions. However, it should also be emphasized that steps taken against terrorists pose many challenges for human rights. International organizations unanimously stress out that when fighting against terrorism, the state must comply with its international obligations. So the fight against terrorism poses many challenges for countries - on one hand, they have a responsibility to protect their citizens, on the other hand, they have to respect the fundamental rights of other people and also terrorists (Vasiliauskienè, 2014, p. 7-9).

After events of 11 September, 2002, threat of terrorism in the US has appeared in the first lines of the security strategies of the most important policies in almost all countries of the world - at least in the so-called Western world, regardless of their previous experience of terrorism, foreign policy and interests, perception of terrorism threat in society. Why did terrorism and the fight against terrorism in the wider part of the world suddenly have become a top priority? First of all, due to naturally grown threat of terrorism, new terrorism trends and the increasing fatality and globalization, after which the consequences of terrorist acts become a threat for many, regardless of what was the original target of terrorists. The fight against terrorism is often used as an instrument of foreign and domestic policy in the Western democracies. Secondly, terrorism is recognized as new, specific threat and special means of combat are acceptable and justifiable, therefore it can become a powerful tool in foreign policy and protecting the state's interests. The fight against terrorism today is the main acceptable excuse for war and economic intervention. Third, some experts of security policy say that at the end of the Cold War, politicians and experts of security in the United States and many other countries had an interest to find a new great „enemy“. The reduction of military threats in many countries caused tension between the allocation of funds for national defence and other, mostly social, policies. Also, emphasizing the threat of terrorism and prioritizing the fight against it ensure public support and encouragement not only for larger funding, but also for creating new special institutions or empowerment of existing ones, because it is difficult to criticize the fight against terrorism or be against the mitigation of terrorism threat (Dranseikaite, 2002, p. 8, 19).

As for the European Union's response to international terrorism it should be noted that the EU's approach to terrorism is enshrined in the EU Treaty of Lisbon. In the EU, both civil and military operational capability can be used for operations outside the EU. The EU also has its own anti-terrorism strategy or action plan. The antiterrorism action plan of EU includes four key counter-terrorism areas: 1) prevention; 2) protection; 3) prosecution; 4) responses. Prevention area mainly fight against radicalization and recruitment of terrorists. Methods of terrorist acts, channels of information dissemination and sources of propaganda are being identified in this place. These tasks are also set for the EU member states and the EU as an organization helps to coordinate it, ensures processes of sharing best practice. Security area is intended to ensure the reduction of the vulnerability of potential targets and to reduce the effect of possible violation. The EU aims to set common actions in the 
areas of border security, transport and other cross-border transport infrastructure protection. This section seeks to minimize the road, rail, air and seaport insecurity. Prosecution area is concentrated in the persecution of terrorists, trace and destroy of terrorist networks. The goal is to prevent the possibility for terrorists to access the means used for terrorism, as well as prevent terrorists from access to their funding sources, disturb or destroy their communication methods. In the last area of response, the EU focuses on the actions in the event of a terrorist attack. This area includes a variety of steps in response to the crisis (http://eur-lex.europa.eu/legal-content/ EN/TXT/?uri=URISERV:133275).

After intensification of the democracy in the world, the USA's trusteeship has become no longer necessary for old world. The countries began to claim to their interests on their own, to express them openly, to defend and to fight for them. For countries that are becoming more powerful, such as Russia, nobody will prevent to model a priori situation that it will begin to defend the world from the USA "s "trusteeship" and so the areas of two superpowerful countries " "trusteeship" will intercross. In view of the fact that the Russian nuclear armament is one of the obstacles for the US military invasion to other countries, antagonism between Russia and America is inevitably expectable, if these countries will not look for compromise solutions. In recent years, during Russia's fighting against Chechen terrorism, it is opportune to support the concept of universal terrorism promoted by the USA, however, after finally fighting Chechens in Russia, Russia's invasion to the other world countries and junction with the USA is inevitable. Today, such invasion is possible under flag of universal terrorism, so that the concept of terrorism is thrown to the international community. Growing oligarchic system in the USA though will inevitably intensify the society's confrontation in this country, so internal unrest and conflicts will arise in the country. On the contrary, democratic processes will intensify in Russia, which will eventually make the country the oligarchic empire having the ambition to be the leader in world's politics. In other countries, when the democratic processes will become stronger, the countries will become stronger too and will be able to offend influence of big countries such as the USA, Russia, China in more complicated ways than terrorism, therefore terrorism will gain more complicated forms of conflict - more organised forces directed not only to the civilian population. The military conflicts between countries and the threat of World War are not rejected too.

As the democratic processes will become stronger, the third world countries will be more open to solve the problems between them. The strongest oligarchic countries will wane because of their internal contradictions, so eventually in persistence of conflicts the countries will rationally understand that they are forced to seek for compromise and peace. This social phenomenon - terrorism - has been extending its scope and has been intesifying, and by its content is acquiring the form of alternative war. The situation presses for urgent measures of prevention, as a further development of the phenomenon may lead to catastrophic results. In order to work out preventive measures aimed at neutralization of terrorism, it is imperative to find out the reasons of the phenomenon, as the preventive measures must be firstly targeted at elimination of the reasons. The modern fight against terrorism is characterized by internal contradictions. The threat to human rights is not only terrorism, but also the fight against terrorism itself, because usually it is changed into the fight against terrorists. Such change of fighting objects requires giving a priority not to legal and social means but to political and military ones. This distorts the essence of terrorism as a social phenomenon, so the fight is directed not to the causes of the phenomenon, but to the extent of its consequences. Giving preference to political, military combat means provokes state terrorism: countries, which call themselves democratic, begin to resist terrorism using means that are not inherent to democracy, which eliminating individual terrorists pose a threat to their own civilians, which they seek to defend. Therefore, terrorism should be seen as a complex social phenomenon. In the fight against terrorism, the priority should be given not to political and military but to legal, social means, in particular the law and justice, which requires individuals and societies prone to terrorist activities to change towards implementing consistent law and justice. Justice, invoked to overcome terrorism, is understood as a system of three procedures: tolerance of contrary interests; combination of contrary interests searching for compromise, establishing a rule of conduct, acquiring the form of balance between the rights and obligations; recognition of the universality of human rights (Vaišvila, 2005, p.17).

As the democratic processes will become stronger in the world, it is likely that the international community will use means of compromise to seek the stability and will be open to consolidation of stability. Only with the 
use of compromise means it can only be possible to restore the legal balance of damaged rights and obligations of community. Only with these means it is possible to achieve the peaceful regulation of terrorism and other conflicts which occur because of violated balance of rights and obligations.

\section{Conclusions}

1. Concept of terrorism is a key element when trying to coordinate international cooperation based on the current rules of war, separating terrorism from criminal facts and from the open war between the dissenting groups that is clearly visible as result of mental retardation. When there is no clear definition of terrorism and its causal relations are acceptable to all, questions concerning the scope of the fight against terrorism arise. In this case, we cannot be sure that modern democratic countries use the correct definition of terrorism in all cases and do not violate the human rights when fighting against terrorists. Even more doubts about the actions of democratic countries participating actively in fight against terrorism arise. The uncertainty of terrorism concept is being used to conceal violations of the human rights. The concept of terrorism cannot be separated from the disclosure of causation of this phenomenon.

2. The reasons of terrorism and other conflicts are similar, but there are different means and ways. Three of them characterize terrorism: 1) intentional usage of violence, 2) directed to civilians or civil objects, 3 ) in order to achieve the political goals.

3. Terrorism is a result of the balance infringement of the countries' relationships rights and duties. Terrorism, as a low-cost way of fighting, becomes the only way for the weaker party to express and declare its requirements for a stronger party of the conflict, which rejects a compromise peace.

4. Democracy progresses there, where it is weak and regresses there, where it was strong. Liberating society of the new world democratic states declares more interest while clan of old democracies" oligarchs do not want to to give up their influence -"trusteeship", i.e. the economic and other areas of interest. And then the conflict arise, that the oligarch, still economically and well performing countries do not have reasons to find a compromise. And new, still not powerful countries, incapable to defend their interests in open processes, are left only radical methods of fight that at first distinguishes their conditional cheapness and great psychological influence. So this is a reason why terrorizm is becoming so popular in the world and which is often the only way to fight for rights.

5. The concept of global terrorism has neither historic nor social justification, because it does not correspond to the actual situation. The universal concept of terrorism is necessary only to those old world countries, that regard themselves developed and need an excuse to constantly control the situation and interfere to constant wars of the third world, to suppress them and never finish this process.

\section{References}

Brzezinski, Zbigniew. The Grand Chessboard. American Primacy and its Geostrategic Imperatives. (New York: Basic Books, 1997).

Diržytė, Aistė, and Patapas Aleksandras. „Terorizmo sociopsichologiniai ypatumai“ [Terrorism sociopsychological peculiarities]. Jurisprudencija 38 (30) (2003): 30-38.

Dranseikaite, Edita. „Globalizacija ir naujo tipo grèsmes: terorizmas“ [Globalization and new types of threats: terrorism]. In: Lietuvos metiné strategine apžvalga 2002. [Lithuanian Annual Strategic Review], t. 1 (2002), 17-32.

Gilpin, Robert, Global Political Economy. (Princeton University Press, 2001).

Gutauskas, Aurelijus, Kalesnykas, Raimundas, Petrošius, Darius. „Terorizmas ir jo prevencijos Lietuvoje problema“ [Terrorism and problem of its prevention in Lithuania] Jurisprudencija 63(55) (2004): 24-45. https://www.mruni.eu/upload/iblock/75a/002_gutauskas_kalesnykas_petrosius.pdf

Hudson, Rex A. The Sociology and Psychology of Terrorims. Report Prepared under an Interagency Agreement by the Federal Research Division. (Library of Congress, 1999). 
Huntington Samuel P., The Clash of Civilizations and the Remaking of World Order. (London: Touchstone Books, 1998).

Ivančík, R.; Nečas, P. 2017. Towards enhanced security: defense expenditures in the member states of the European Union, Journal of Security and Sustainability Issues 6(3): 373-382. https://doi.org/10.9770/jssi.2017.6.3(4).

Jongman, Albert J., Schmid Alex P. Political Terrorism. (Amsterdam: SWIDOC, 1988).

Kennedy, Paul. The Rise and Fall of Great Powers. (London: Fontana Press, 1989).

Kissinger, Henry. Does America need a Foreign Policy? (New York: Simon and Schuster, 2001).

Kuzavinis, Kazimieras. Lotynų-lietuvių kalbų žodynas [Latin-Lithuanina dictionary]. (Vilnius: Mokslo ir enciklopedijų leidykla, 1996) [Vilnius: Science and Encyklopedia House, 1996].

Paukšte, Arūnas. „Pagrindinės šiuolaikinio terorizmo ideologinės kryptys“ [Main ideological directions of contemporary terrorism). Jurisprudencija 68 (60) 2005: 83-90. https://www.mruni.eu/upload/iblock/89e/011_paukste.pdf

Piazza, James A. „Rooted in Poverty?: Terrorism, Poor Economic Development, and Social Cleavages“. Terrorism and Political Violence 18 2006: 159-175.

Vytautas Šlapkauskas, Vytautas. „Visuomenès saugumo ir žmogaus teisių ryšys kaip antiterorizmo ideologijos legitimacijos pagrindas“ [Public security and human rights in relation to anti-terrorism ideology legitimizing the basis], Jurisprudencija 68(60) (2005): 25-34. https://www.mruni.eu/upload/iblock/e6f/4_slapkauskas.pdf

Teivāns-Treinovskis, J.; Amosova, J.; Načisčionis, J.; N̦esterova, M. 2016. Country's development and safety: violent crimes in crime structure, Journal of Security and Sustainability Issues 6(2): 227-233. https://doi.org/10.9770/jssi.2016.6.2(3)

Todd, Emmanuel. Après l'empire. Essai sur la décomposition du système américain. [After the empire. Essay on the decomposition of the American system], (Gallimard, 2004).

Tumalavičius, V.; Veikša, I.; Načisčionis, J.; Zahars, V.; Draskovic, V. 2017. issues of state and society security (Part I): Ensuring public security in the fight against crime, Journal of Security and Sustainability Issues 6(3): 401-418. https://doi.org/10.9770/jssi.2017.6.3(7)

Vaišvila, Alfonsas. „Terorizmas ir kova su terorizmu - dvi grèsmės žmogaus teisėms (metodologinis aspektas)“ [Terrorism and the fight against terrorism - two threats to the human rights (methological aspect)], Jurisprudencija 68(60) (2005): 11-19.

Vasiliauskienė, Violeta. „Kova su terorizmu tarptautinès humanitarinės teisès kontekste“. Daktaro disertacija, socialiniai mokslai, teisė (01S), Vilnius: Vilniaus universitetas [The fight against terrorism in the context of international humanitarian law. Doctoral dissertation, Social Sciences, Law (01S), Vilnius: Vilnius University], 2014. 